\title{
MEASURED PROPERTIES OF THE ANTARCTIC
}

\section{ICE SHEET: SURFACE CONFIGURATION, ICE THICKNESS, VOLUME AND BEDROCK}

\section{CHARACTERISTICS}

\author{
by \\ D. J. Drewry, S. R. Jordan and E. Jankowski \\ (Scott Polar Research Institute, University of Cambridge, Cambridge CB2 1ER, England)
}

\section{ABSTRACT}

Results of airborne radio echo-sounding (RES) in Antarctica are presented. Flight tracks covering $50 \%$ of the Antarctic ice sheet on a 50 to $100 \mathrm{~km}$ square grid, flown using inertial navigation, have errors $<<5 \mathrm{~km}$. I ce thicknesses determined from 35,60 , and $300 \mathrm{MHz}$ RES records are accurate to $10 \mathrm{~m}$ or $1.5 \%$ thickness (whichever is greater). Altimetry, determining surface and sub-surface elevations, after corrections have errors $<<50 \mathrm{~m}$. An up-to-date coastin complled from satellite imagery and all recent sources has frequencies for various coastal types of: ice shelves (44\%), ice streams/outlet glaciers (13\%), ice walls (38\%), and rocks $(5 \%)$. A new map of the ice sheet surface has been compiled from 101000 RES data points, 5000 Tropical Wind, Energy conversion and Reference Level Experiment (TWERLE) balloon altimetry points, geodetic satellite and selected traverse elevations. The volume of the Antarctic ice sheet including ice shelves has been calculated principally from RES data using various techniques as $30.11 \pm 2.5 \times 10^{6} \mathrm{~km}^{3}$. Frequency distributions for subglacial bedrock elevations for East and West Antarctica are presented. They conform approximately to Gaussian (normal) functions.

\section{INTRODUCTION}

In this paper we describe results of the compi1ation of data on Antarctic ice-sheet surface morphology, bedrock configuration, and ice thickness, based on data obtained primarily from airborne RES a) though other sources are used where appropriate. Knowledge of these three parameters has increased measurably since the last symposium on Antarctic glaciology in 1968. Whereas oversnow traverses conducting barometric altimetry and seismic shooting were typical of the $1950 \mathrm{~s}$ and $1960 \mathrm{~s}$, airborne RES and satellite systems are currently empioyed.

Maps depicting ice-sheet morphology, bedrock configuration, and ice thickness are to be printed in colour and published as part of an Antarctic glaciological and geophysical folio by the Scott Polar Research Institute (SPRI) in 1982 (Drewry and Jordan 1980, Drewry in press).

\section{RADIO ECHO-SOUNDING (RES)}

$50 \%$ of the Antarctic ice sheet $\left(6.8 \times 10^{6} \mathrm{~km}^{2}\right)$ has been surveyed during the last decade on a 50 to
$100 \mathrm{~km}$ square grid using airborne RES techniques in a SPRI-US National Science Foundation (NSF)-Technical University of Denmark (TUD) programme. Descriptions of the technique and systems have been given el sewhere (Evans and Smith 1969, Robin 1975, Skou and Sondergaard 1976, Christensen 1970, Drewry and Meldrum 1978, Drewry 1981). Pertinent to this study are the methods of reduction of data to achieve accurate surface and subglacial elevations. A flow chart outlining the reduction process is shown in Figure 1 .

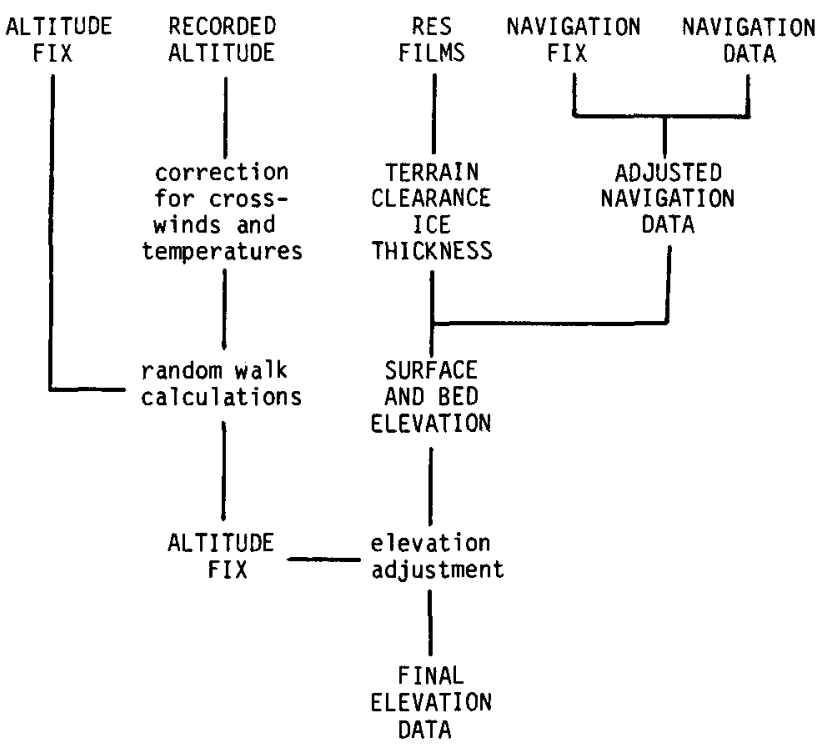

Fig.1. Flow chart for reduction of RES data. Crosswind and temperature corrections were applied to 1974-75 data only.

\subsection{Navigation}

ATl filights in this study were conducted using one or two inertial navigation systems (INS) of Litton LTN-51 type. Output froin the INS (1atitude, longitude, drift angle, heading, track angle, ground speed) were recorded either on punched paper tape (1971-72, 1974-75 seasons) or on magnetic tape

(1977-78, 1978-79 seasons) at a sampling interval 
(bearing in mind a typical ground speed of $100 \mathrm{~m} \mathrm{~s}^{-1}$ ) of one data frame every $20 \mathrm{~s}(1971-72), 15 \mathrm{~s}$

(1974-75), $0.125 \mathrm{~s}(1977-78)$, and $0.25 \mathrm{~s}(1978-79)$.

A data-logging system developed by the US Naval Weapons Center and made available by NSF was used during the latter two seasons.

Flight tracks derived from INS records have been adjusted to close all available fixes (e.g. terminal fixes, overflown bases and camps, mountains etc., of known position). Al though errors between fixed and unfixed track positions are distributed linearly, such a simple treatment is not ideal due to the complex nature of INS (Kayton 1969) but the small number of fixes on any one flight prevents a more sophisticated distribution of errors. Errors may arise from linear components, oscillating Schuler frequency elements with perturbations introduced by various aircraft manoeuvres. Rose (unpublished) gives a resume of these factors. The small number of fixes on any one flight prevents a more sophisticated distribution of errors.

It is possible to use ice thickness data at the intersection of two different flight lines to deduce the shift necessary for thicknesses to correlate (see Rose unpublished):

$$
h_{1}\left(P_{1}+p_{2}\right)=h_{2}\left(P_{1}+p_{2}\right),
$$

where $h_{n}(p)$ is the ice thickness of flight $n$ at position $p, P_{n}$ is the position at crossing point on flight $n$, and $p_{n}$ is the error in crossing point position on flight $n$.

In general there will be very many possible solutions to Equation (1). Rose found that for West Antarctica a mean shift of flight 1 ines by $2.5 \mathrm{~km}$ would remove errors at $40 \%$ of crossing points, and this distance represents a lower bound for such navigation errors. The maximum difference on a11 Antarctic RES tracks was typically of the order of $8 \mathrm{~km}$ with RMS deviation over a whole flight of 4 to $5 \mathrm{~km}$. In general, therefore, the error in navigation should be $<<5 \mathrm{~km}$ anywhere, corresponding to less than $1 \mathrm{~mm}$ at a mapped scale of 1:5000 000 .

\subsection{Ice thickness}

Aircraft terrain clearance and ice thickness are determined from RES records of echo delays. Received signals on Z-scope traces are usually enhanced by differentiation of signal strength with respect to time. Weak bottom echoes are also enhanced by the integrating effect of slowly moving film and a high pulse repetition frequency (PRF) typically in the order of 15 to $25 \mathrm{kHz}$. Digitization of records gives rise to certain random errors (from equipment and operator inaccuracies). Repeat measurements of a given distance displacement reveal an RMS deviation equivalent to $0.17 \mathrm{us}(25.5 \mathrm{~m}$ in air and $14.3 \mathrm{~m}$ in ice) (Steed unpublished). Oscillograms produced by a Honeywel1 1856A Visicorder during the 1977-78 and 1978-79 seasons allowed improved digitization with RMS deviation of $0.12 \mu \mathrm{s}(18 \mathrm{~m}$ in air and $10.1 \mathrm{~m}$ in ice).

Propagation velocity of radio waves in air is $300 \mathrm{~m} \mathrm{~ms}^{-1}$. Velocity in ice is related to relative permittivity $\varepsilon^{\prime}$. Early estimates from laboratory studies suggested $\varepsilon^{\prime}=3.17 \pm 0.07$ within the frequency range 10 to $10^{5} \mathrm{MHz}$ (Robin and others 1969).

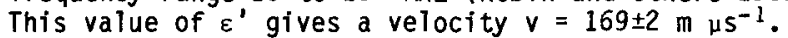
More recent laboratory work, specifically at $60 \mathrm{MHz}$, shows a slight decrease in $\varepsilon^{\prime}$ with temperature but no detectable change with uniaxial compressive stress and resulting plastic flow (Johari and Charette 1975). A value of $168 \mathrm{~m} \mu \mathrm{s}^{-1}$, accurate to about $1 \%$, is suggested by all these results. An interferometric $\log$ of a bore hole on Devon Island, NWT, Canada, by Robin (1975) gave a velocity of $167.7 \pm 0.3 \mathrm{~m} \mathrm{us}^{-1}$ at $440 \mathrm{MHz}$. Shabtaie and others (1980) have used a value of $173 \mathrm{~m} \mathrm{~ms}^{-1}$ for conversion of travel times at Dome $C$ in East Antarctica.

Higher velocities occur as the radio wave passes through low density snow and firn (Shabtaie and Bentley (1982). Robin and others (1969) derived a general solution to correct for this layer by inspection of several depth-density curves which resulted in the addition of an extra delay equivalent to a column of ice of thickness $10 \mathrm{~m}$. This is estimated to be accurate to within $5 \mathrm{~m}$ for all types of firn.

All ice thicknesses reported here have been derived using $\mathrm{v}=168 \mathrm{~m} \mathrm{us}^{-1}+10 \mathrm{~m}$ (firn correction factor).

\subsection{Altimetry}

A7titudes of the ice-sheet surface and subglacial bedrock are determined relative to aircraft height by static pressure measurements using a pressure transducer (Garrett) with a maximum instrumental error of $22 \mathrm{~Pa}$ and an RMS error of $16 \mathrm{~Pa}$ (equivalent to $2.5 \mathrm{~m}$ ). The major sources of error in determining aircraft barometric elevation arise from spatial and temporal changes in constant pressure surfaces associated with with weather systems: variations of up to $150 \mathrm{~m}$ over distances of a few hundreds of kilometres can occur (Steed unpublished). A "crosswind" correction (Rose unpublished) has been applied to some data since the geometrical height of a constant pressure surface will vary (assuming that winds are purely geostrophic). The correction also depends on aircraft latitude, velocity, and drift angle, and accumulates with time during the flight. For 1974-75 data the mean maximum crosswind correction was $83 \pm 3 \mathrm{~m}$. On flights where transducer output was calibrated against aircraft pressure altimeters, corrections are necessary for the departure of the Antarctic atmosphere from the International Standard Atmosphere (ISA). ISA temperature at sea-level is $15^{\circ} \mathrm{C}$, much warmer and less dense than in the Antarctic. Corrections were made based upon the ratio of mean temperature of the actual and ISA air columns, and typically in the range -50 to $-150 \pm 15 \mathrm{~m}$ (Rose unpublished).

Even after application of these corrections icesurface elevations will differ at the intersection of two independent flights. Jankowsk $i$ and Drewry (1981), for instance, found a mean error at crossover points of $47 \pm 44 \mathrm{~m}$ RMS. In order to minimize and redistribute these errors at nodes of the flight line grid and take account of a limited number of control elevations (e.g. geoceiver stations, sea-level, etc.) in producing new surface altitudes a random walk procedure has been employed. The mean elevation value at any one node will, after many thousands of visits during walks which begin and end at control points, converge on a stable solution as errors are redistributed over the whole grid. The results of this procedure were confirmed by a least-squares technique on the same data-set performed by the UK Directorate of Overseas Surveys.

Large-scale systematic errors of the RES survey altimetry after corrections and minimization are estimated for areas well away from control points to be significantly less than $50 \mathrm{~m}$.

\section{ANTARCTIC COASTLINE}

There have been considerable improvements in the mapping of coastal areas of Antarctica in the last decade resulting especially from the use of satellite imagery (Swithinbank 1974, MacDonald 1976, Swithinbank and others 1976). During the compilation of base-map data for the Antarctic glaciological and geophysical folio it was found necessary to produce an up-to-date coastline. The most recent and reliable charts of coastal areas were digitized to produce a coastal outline data base consisting of some $225 \mathrm{k}$ points. In some areas the coast was completely remapped using Landsat images fixed to geodetic ground control. This was undertaken between $120^{\circ} \mathrm{E}$ and $157^{\circ} \mathrm{E}$, along the front of the Ross Ice Shelf and Filchner-Ronne ice shelves. While improvements will continue to be made in the coastal outline of the continent the present map is a reasonably accurate and up-to-date representation. 
TABLE I. COMPARISON OF LENGTHS AND FREQUENCY OF COASTAL TYPES AROUND ANTARCTICA

Type

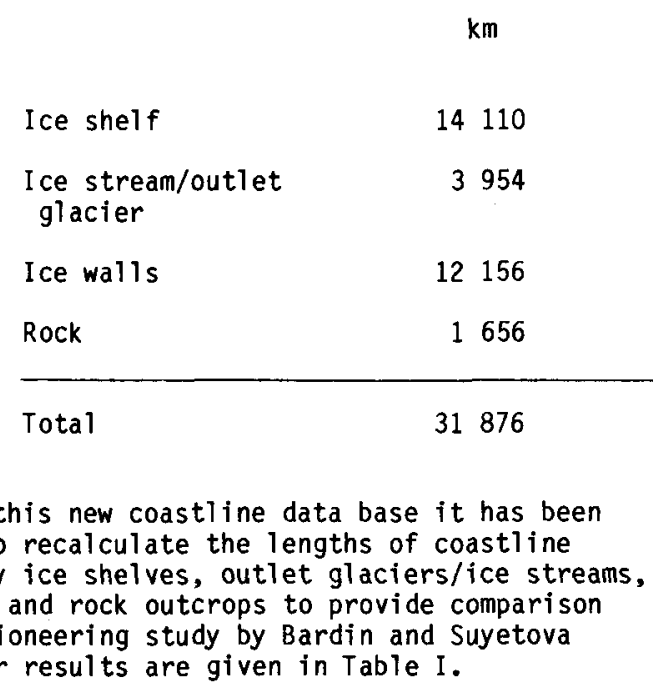

\section{ICE-SHEET SURFACE}

I ce-sheet surface elevations have been contoured at $100 \mathrm{~m}$ intervals from 101000 SPRI RES determinations. TWERLE balloon altimetry (made available by courtesy of Dr Nadav Levanon (Levanon and others 1977, Levanon and Bentley 1979, Levanon 1982), numbering some 5000 points was also added to the data set as were geodetic satellite measurements and selected barometric altimetry from some oversnow traverses. All data were plotted at a compilation scale of $1: 3000000$. RES data were colour-coded and parameter-annotated along flight lines (see Drewry 1975[a]). All other elevation values were plotted to three significant figures. Contouring was then undertaken, independently and by hand, by three persons, results compared, and a final version produced. In mountainous terrain (Transantarctic Mountains, Oronning Maud Land, Prince Charles Mountains, parts of Byrd Land) contours at $500 \mathrm{~m}$ were taken from the Soviet 1:3 000000 map of Antarctica (Ministerstvo Morskogo Flota SSSR 1975). For contours in the Antarctic Peninsula the latest British Antarctic Survey (BAS) maps were used (British Antarctic Survey 1979, Directorate of Overseas Surveys 1981). The resulting ice-sheet surface map will be printed in colour at a scale of $1: 6000000$ in the forthcoming Antarctic glaciological and geophysical folio. Figure 2 presents a small-scale surface map using an interpolation procedure based on a $50 \mathrm{~km}$ sided matrix. Figure 3 is an isometric view of the ice-sheet surface. Between June and October 1978 a $13.5 \mathrm{GHz}$ radar altimeter was flown aboard the satellite Seasat at a mean altitude of $800 \mathrm{~km}$. The inclination of the satellite orbit of $108^{\circ}$ resulted in coverage of coastal areas of Antarctica (to latitude $72^{\circ} \mathrm{S}$ ). The altimeter had a precision of $\sim 100 \mathrm{~mm}$ but due to the footprint size $(12 \mathrm{~km})$ over rough, sloping ice terrain and problems with interpretation of returned radar waveforms this was degraded to between 1 and $5 \mathrm{~m}$. Analysis of derived surface altitudes by Zwally and others (1982) reveals a pattern for coastal East Antarctica which substantiially confirms the contours in Figure 2 .

\section{ICE-SHEET THICKNESS AND ICE VOLUME}

A11 RES ice thickness data (SPRI and selected other sources) have been combined with existing depth determinations from seismic shooting to produce a contour map for the whole continent. As a result it has been possible to derive estimates for the volume of ice in Antarctica. Volume is given by:
Bardin and Suyetova (1967)

$\%$

$\mathrm{km}$

$\%$

44

13660

45.5

13

2860

9.5

38

11090

37.0

5

2420

8.0

30030

$$
V=\iint_{a} h d a
$$

where $h$ is the ice thickness and $a$ is the area.

The problem is to find a satisfactory method of estimating Equation (2). Several techniques are available. A contour map of ice thickness enables the area occupied by each ice-thickness band to be specified and used in construction of a hypsometric curve which may then be integrated to give ice volume. An alter; native method, which has been adopted in this study, is to use equally spaced ice-thickness data points, averaged within each cell of a matrix of arbitrary size superimposed over Antarctica and taking account of ice in ice-shelf and grounded-ice areas. Where no measured values are available an estimated value based on adjacent or regional values has been specified. Total volume is then the sum of all the cell volumes:

$$
V=\sum_{i=1}^{n} \Delta i,
$$

where $\Delta i$ is mean ice volume in cell of unit area.

A further method assumes that since the RES grid covers a very large proportion of the area of West Antarctica and over a third of East Antarctica the values taken by the means of all RES determinations within these areas will be representative of the larger region. The product of regional areas and average ice thickness yields the volume. Corrections can be made for areas of outcrop, and any bias in RES depths towards shallower thicknesses (i.e. thickest ice may not be recorded). Continental volume is then:

$$
\begin{aligned}
V= & {\left[\left(A_{i} \bar{h}_{j}\right)+\left(A_{g}-A_{m}\right) \bar{h}_{g} \cdot Q\right]_{e}+\left[\left(A_{i} \bar{h}_{i}\right)+\left(A_{g}-A_{m}\right) \bar{h}_{g} \cdot Q\right]_{w} } \\
& +\left[\left(A_{j} \bar{h}_{i}\right)+\left(A_{g}-A_{m}\right) \bar{h}_{g} \cdot Q\right]_{p}+\left(A_{i} \bar{h}_{i}\right)_{r}+\left(A_{i} \bar{h}_{i}\right)_{f}
\end{aligned}
$$

where $A_{g}$ is area of grounded ice including ice rises, $A_{i}$ is area of ice shelf, $A_{m}$ is area occupied by rock outcrop, $\bar{h}_{g}$ is mean thickness of grounded ice, $\bar{h}_{j}$ is mean thickness of ice shelf, and $Q$ is correction factor for shallow ice bias in measurement. This has been derived using the ratio of RES flight track where bed echoes were not recorded due to system performance limitations to track with detectable bed returns. Major subscripts refer to East Antarctica: e, West Antarctica: $w$, Ross Ice Shelf: $r$, Filchner-Ronne ice shelves: $f$, Antarctic Peninsula: $p$, and mountain or rock outcrop: $m$.

Space does not permit the detailed tabulation and comparison of the results of these two methods 


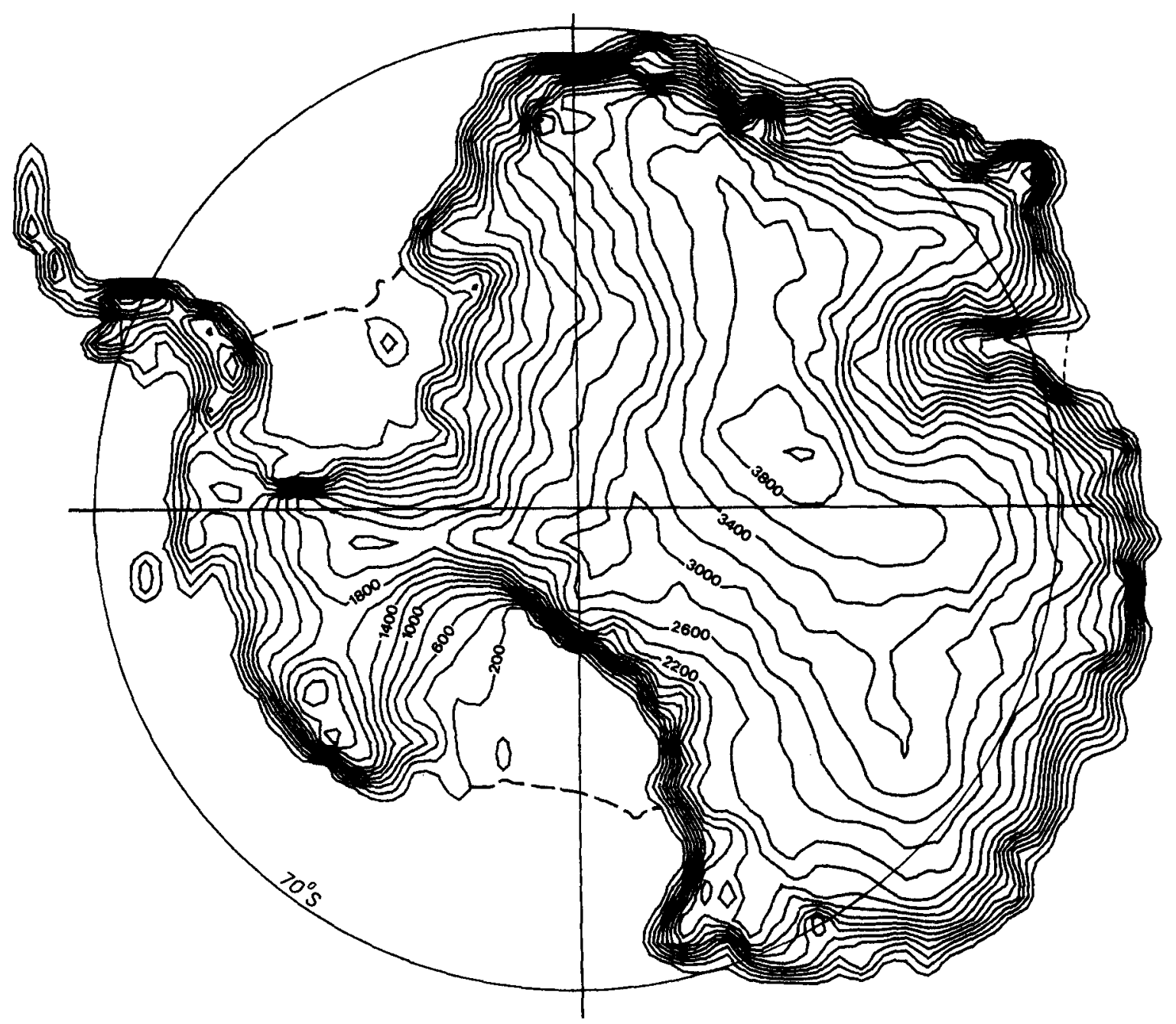

Fig.2. Contour map of the surface of the Antarctic ice sheet based upon RES, TWERLE, and some traverse data using a simple cubic interpolation and a matrix of size $50 \mathrm{~km}$. Note that the lowest contour is $200 \mathrm{~m}$ and the coastline (except edge of major ice shelves) is not shown. The detailed contour map will be published at a scale of 1:6000 000 (Drewry in press).

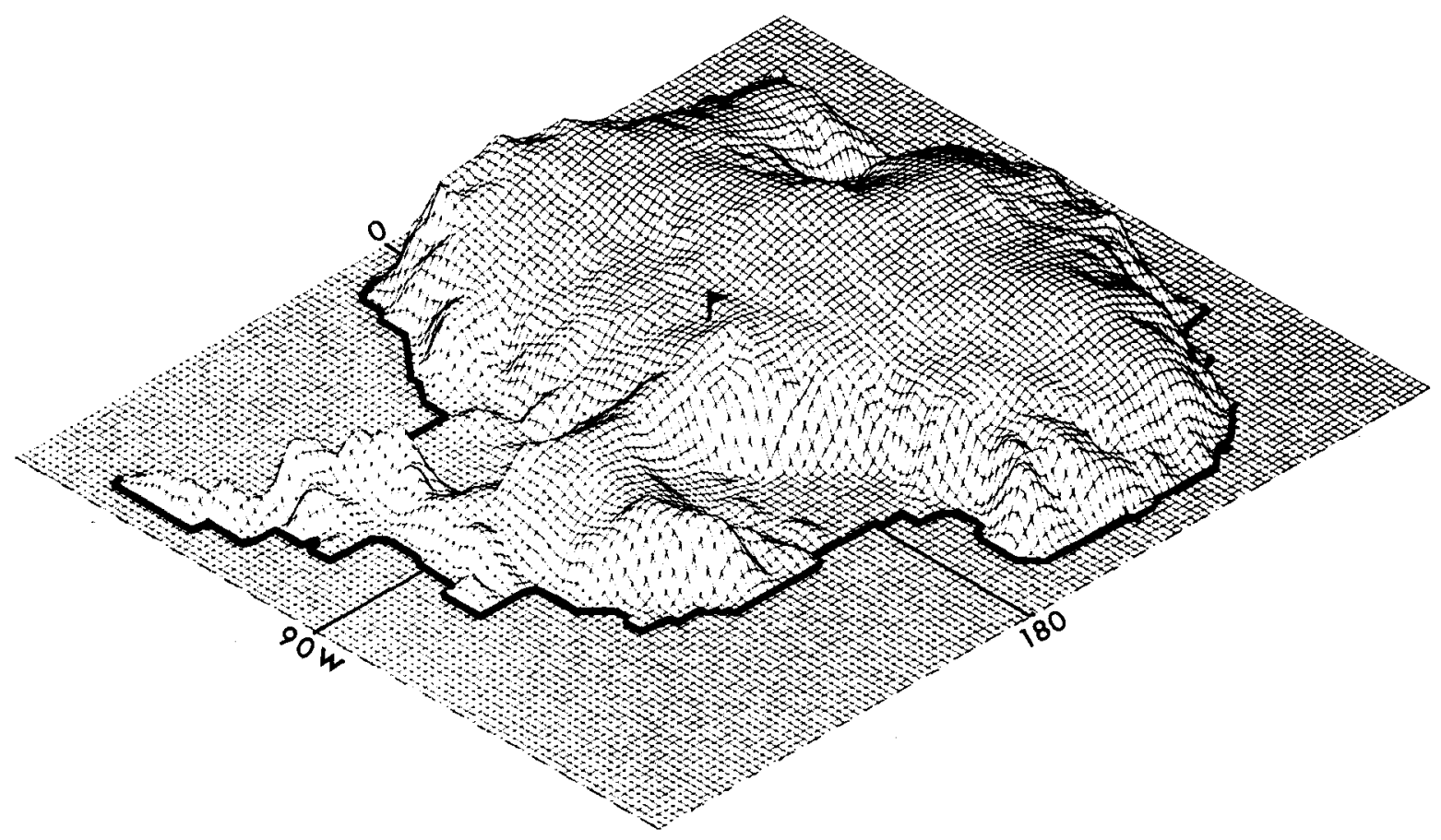

Fig.3. I sonetric view of the surface of the Antarctic ice sheet, based upon $50 \mathrm{~km}$ square matrix. Mountainous areas have been omitted. Note the steepness of coastal areas of the ice sheet, the effects of some of the large drainage basins (e.g. Lambert Glacier) and subtle surface relief. 
TABLE II. AREA, ICE THICKNESS, AND ICE VOLUME FOR ANTARCTIC ICE SHEET (Equation (4))

Region
East Antarctica
Grounded ice,
$Q=1.05$
Ice shelves
Ice rises
Total ice
Total area
including
$2 \%$ rock

$\begin{array}{ccc}\text { Area } & \overline{\mathrm{h}} & \text { Volume } \\ \left(\mathrm{km}^{2}\right) & (\mathrm{m}) & \left(10^{3} \mathrm{~km}^{3}\right)\end{array}$

$\begin{array}{rrrrr}9855 & 570 & 2630(a) & 25920.1 \\ & & & \\ 293 & 510^{*} & 400(b) & 117.4 \\ 4 & 090^{*} & 400(\mathrm{c}) & 1.6 \\ 10153 & 170 & & 26039.2\end{array}$

\section{West Antarctica}

\begin{tabular}{|c|c|}
\hline $\begin{array}{c}\text { Grounded ice, } \\
Q=1.1\end{array}$ & 1809760 \\
\hline Ice shelves & $104860^{\star}$ \\
\hline Ice rises & $3550^{\star}$ \\
\hline Total ice & 1918170 \\
\hline $\begin{array}{l}\text { Total area } \\
\text { including } \\
3 \% \text { rock }\end{array}$ & $1974140 *$ \\
\hline
\end{tabular}

\section{Antarctic Peninsula}

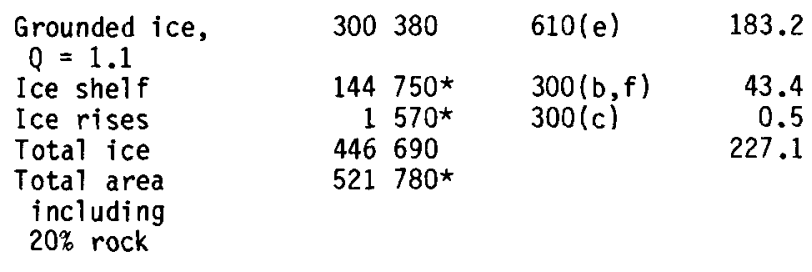

\section{Ross Ice Shelf}

$\begin{array}{lrlr}\text { Ice shelf } & 525840 & 427(\mathrm{~g}) & 224.5 \\ \text { Ice rises } & 10320^{\star} & 500(\mathrm{~g}) & 5.1 \\ \text { Total area } & 536070^{\star} & & 229.6\end{array}$

\section{Ronne-Filchner ice shelves}

\begin{tabular}{|c|c|c|c|c|c|}
\hline $\begin{array}{l}\text { Ice shelf } \\
\text { Ice rises } \\
\text { Total area }\end{array}$ & $\begin{array}{r}472 \\
59 \\
532\end{array}$ & $\begin{array}{l}760 \\
440^{\star} \\
200^{*}\end{array}$ & $\begin{array}{l}650(j) \\
750\end{array}$ & & $\begin{array}{r}307.3 \\
44.6 \\
351.9\end{array}$ \\
\hline $\begin{array}{l}\text { Grounded ice } \\
\text { Ice shelf } \\
\text { Ice rises } \\
\text { Ice shelf }+ \\
\text { ice rises } \\
\text { Rock outcrop }\end{array}$ & $\begin{array}{rr}11 & 965 \\
1 & 541 \\
& 78 \\
1 & 620 \\
& \\
& 331\end{array}$ & $\begin{array}{l}700 \\
710 \\
970 \\
680 \\
610\end{array}$ & $\begin{array}{l}2450 \\
475(\mathrm{k}) \\
670(\mathrm{~m})\end{array}$ & 29 & $\begin{array}{r}324.7 \\
732.9 \\
53.1 \\
785.1\end{array}$ \\
\hline Total & 13917 & 990 & 2160 & 30 & 109.8 \\
\hline
\end{tabular}

* Directly measured (all others calculated).

(Equations (3) and (4)) but a difference of less than $2 \%$ was found. We have 1 isted some of the results calculated using Equation (4) which provides a natural breakdown for the principal regions of Antarctica (Table II). The total volume of ice is found to be just over $30 \times 10^{6} \mathrm{~km}^{3}$.

\subsection{Estimation of errors}

The error associated with this calculation of total ice volume is estimated as $\pm 2.5 \times 10^{6} \mathrm{~km}^{3}$, made up of contributions from uncertainty in area and ice thickness measurements.

The area of Antarctica was determined using the coastline compilation discussed in section 3 projected on a Lambert azimuthal equal-area net at a
Notes on Table II

(a) This value was derived from 28537 RES determinations covering $>1 / 3$ East Antarctica, with mean of $2513 \mathrm{~m}$ and RMS deviation of $2668 \mathrm{~m}$. Q factor in Equation (4) was 1.047 .

(b) Value derived using the relationship given in Equation (5).

(c) Inspection of ice-thickness values from ice shelves around Antarctica indicates that ice rises of small dimensions (width 40 to $60 \mathrm{~km}$ ) have similar ice thickness to adjacent ice shelf (see inset in Drewry (1979: fig.5)).

(d) Value derived from 12826 RES determinations covering $80 \%$ of West Antarctica (see Fig.1) of mean $1620 \mathrm{~m}$ and RMS deviation $1765 \mathrm{~m}$. Q factor in Equation (4) was 1.1 .

(e) Value derived using the regional maps with plotted ice thicknesses of Smith (1972). A mean value of $554 \mathrm{~m}$ is given from several hundred determinations with RMS deviation of $320 \mathrm{~m}$. Q factor was 1.1 . (f) Values were also derived using the ice-thickness data of Smith (1972).

(g) I ce-shelf thickness was derived from 5007 RES determinations giving mean of $427 \mathrm{~m}$ and RMS deviation of $440 \mathrm{~m}$, while ice-rise data were taken from RES data and those of Thomas and others (1980).

(j) Ice-shelf thickness was derived from 930 RES determinations giving mean of $650 \mathrm{~m}$ and RMS of $312 \mathrm{~m}$. I ce-rise thickness obtained in a similar manner and the substantially thicker ice is due to effects of Berkner I s land.

(k) This figure is biased by the thicker ice of Ross and Ronne-Filchner $i c e$ shelves. See also comment $(c)$ above.

(m) This figure is biased by the very large and thick ice of Berkner Island in Ronne-Filchner ice shelves.

scale of 1:6000 000. A magneto-strictive digitizing system was employed which gave an accuracy better than $1 \%$ on repeated measurements of the same test areas. This figure of $<1 \%$ embodies both machine and operator randoin errors. In view of the fact that mapping of the Antarctic coastline is of variable quality and many of the boundaries are highly mobile (i.e. the fronts of ice shelves and outlet glaciers) a likely error in measured sector areas is $<3 \%$. This would give rise to an uncertainty in calculation of total Antarctic ice volume of $1.0 \times 10^{6} \mathrm{~km}^{3}$.

The ice thicknesses given in Table II were derived from several sources (see notes for Table III) but primarily from RES measurements. Of critical importance in calculation of volume is the accurate assessment of the mean value for the larger areas such as East and West Antarctica. Just over one-third of East Antarctica is covered by RES grid. Some 28500 equally-spaced ice-thickness determinations in this area were used to derive a mean value which was considered representative and applied to the whole region. Data froin the limited number of oversnow traverses in that part of Antarctica not covered by dense RES grids show that the variations in ice thickness are similar to those observed from areas of RES coverage.

Since the ice sheet mantles a wide variety of subglacial topography the RMS deviation of thickness is high. The standard error of the mean (SEM) at the 99\% level for the calculated thickness values is in the order of $\pm 50 \mathrm{~m}$. In West Antarctica where the RES grid gives very good coverage of the whole area the SEM is also $\pm 50 \mathrm{~m}$.

An uncertainty of $\pm 50 \mathrm{~m}$ in calculated mean thickness values for East and West Antarctica gives a combined uncertainty in ice volume of $\pm 0.52 \times 10^{6} \mathrm{~km}^{3}$. Taking into account extrapolation of the sample mean into areas of less or no measured 
Drewry and others: Measured properties of the Antarctic ice sheet

TABLE III. COMPARISON OF MORPHOMETRIC DATA FOR ANTARCTIC ICE SHEET

\begin{tabular}{|c|c|c|c|c|c|}
\hline Parameter & $\begin{array}{l}\text { Thiel } \\
\text { (1962) }\end{array}$ & $\begin{array}{l}\text { Bardin and } \\
\text { Suyetova } \\
\text { (1967) }\end{array}$ & $\begin{array}{c}\text { Vinnik and } \\
\text { others }(1976) \\
\text { (cf. Averyanov }(1980))\end{array}$ & \multicolumn{2}{|c|}{ Thts paper } \\
\hline \multicolumn{6}{|l|}{ Area $\left(10^{6} \mathrm{~km}^{2}\right)$} \\
\hline $\begin{array}{l}\text { Conterminus Antarctica } \\
\text { (including ice-free } \\
\text { terrain) }\end{array}$ & 13.660 & 13.975 & 13.978 & 13.918 & $100 \%$ \\
\hline $\begin{array}{l}\text { Grounded ice sheet } \\
\text { (including ice rises) }\end{array}$ & 12.090 & 12.393 & 12.370 & 12.045 & $86.6 \%$ \\
\hline $\begin{array}{l}\text { Ice shelves } \\
\text { (exciuding ice rises) }\end{array}$ & - & 1.460 & 1.570 & 1.542 & $11.0 \%$ \\
\hline All ice sheet & 13.470 & 13.975 & 13.940 & 13.586 & $97.6 \%$ \\
\hline Ice-free area (rock) & 0.190 & & $0.03-0.04$ & 0.332 & $2.4 \%$ \\
\hline \multicolumn{6}{|l|}{ Ice Volume $\left(10^{6} \mathrm{~km}^{3}\right)$} \\
\hline Conterminus Antarctica & 24.300 & 24.031 & 24.903 & 30.110 & $100 \%$ \\
\hline $\begin{array}{l}\text { Grounded ice } \\
\text { (including ice rises) }\end{array}$ & 23.800 & 23.449 & 24.290 & 29.378 & $97.6 \%$ \\
\hline $\begin{array}{l}\text { Ice shelves } \\
\text { (excluding ice rises) }\end{array}$ & 0.500 & 0.582 & 0.610 & 0.732 & $2.4 \%$ \\
\hline \multicolumn{6}{|l|}{ Ice thickness $(\mathrm{m})$} \\
\hline Conterminus Antarctica & 1810 & 1720 & 1786 & 2450 & \\
\hline Grounded ice & 1970 & 1880 & 1964 & - & \\
\hline (i) East Antarctica & - & 1980 & 2070 & 2638 & \\
\hline (ii) West Antarctica & - & 1440 & 930 & 1782 & \\
\hline Ice shelves & 380 & - & 390 & 475 & \\
\hline
\end{tabular}

data and inspection of ice-thickness variations on avallable oversnow traverses suggest that

$\pm 1 \times 110^{6} \mathrm{~km}^{3}$ might be a realistic error in esti mates of the ice volume deriving from thickness uncertainty.

For the major ice shelves (Ross and FilchnerRonne) there is very good RES coverage and due to their relatively uniform characteristics the icethickness means may be considered representative. SEM for the Ross Ice Shelf is, for example $\pm 20 \mathrm{~m}$. For the smaller ice shelves in East Antarctica, West Antarctica, and the Antarctic Peninsula thicknesses have been derived from a 11 mited number of RES and selsmic soundings and application of the relationship, determined by Crary and others (1962: fig.14) from the Ross Ice Shelf, between observed surface elevations $S$ and ice thickness $h$ :

$$
h=(S-15.6) / 0.108 \text {. }
$$

In general all ice-shelf thicknesses for these smaller shelves will lie between 100 and $500 \mathrm{~m}$. Given a total area for them of $0.54310^{6} \mathrm{~km}^{2}$ the deviation in ice volume from that calculated using a mean based upon Equation (5) is not likely to be more than $0.2 \times 10^{6} \mathrm{~km}^{3}$. In the Antarctic Peninsula a high proportion of terrain is ice-free $(\sim 20 \%)$ and else- where subglacial topography is extremely rugged. Al though considerable RES has been conducted in the peninsula area there are only a few published sources of ice-thickness data (see Swithinbank 1968, Smith 1972, Swithinbank 1977, Crabtree 1981). Nevertheless these have proved adequate for basic estimation of ice volumes within the glaclerized (grounded ice) area $\left(0.300 \times 10^{6} \mathrm{~km}^{2}\right)$. Uncertainty in average ice thickness as high as $\pm 500 \mathrm{~m}$ would only change the continental ice volume by $\pm 0.15 \times 10^{6} \mathrm{~km}^{3}$. The total error in fce volume is thus the sum of these smaller contributions: $\pm(1.0+1.0+0.2+0.15)$, say $\pm 2.5 \times 10^{6} \mathrm{~km}^{3}$.

5.2 Discussion of areas and ice volumes

TabTe III compares the data calculated in this paper with other recent compllations. In many cases it has proved impossible to compare results for subcontinental areas due to the lack of accurate definition of the regions used in published accounts.

The estimate of area of the conterminous Antarctic (i.e. including offshore islands joined by ice shelves) has not changed substantially in recent years. There is less than $0.5 \%$ difference between the Soviet figure accepted by Averyanov (1980) and that calculated here. As our errors in deriving areas are of the order of $1 \%$ the two figures may be taken as identical. Similar comments are applicable 
to the areas of grounded ice sheet and ice shelf. We believe, however, that the area of rock outcrop given by Korotkevich (1968), 0.03 to $0.0410^{6} \mathrm{~km}^{2}$, is too low and suggest a vaiue an order of magnitude larger.

The considerably higher ice volumes (Table III) are due to greater values for ice thickness. All the previous estimates were based upon a total data set numbering some 1500 unevenly scattered seismic reflection determinations and approximately 9000 less reliable gravity observations. Continuous RES over half of the continent has now provided 77000 digitized values from the SPRI programme alone. They indicate that average ice-thickness values are considerably in excess of previous estimates. It should also be borne in mind that comparison of RES with seismic-gravity ice-thickness measurements has revealed substantial underestimation of ice depths on several major oversnow traverses in East Antarctica (Drewry 1975[b]).

BEDROCK EL. FOR ICE CPP
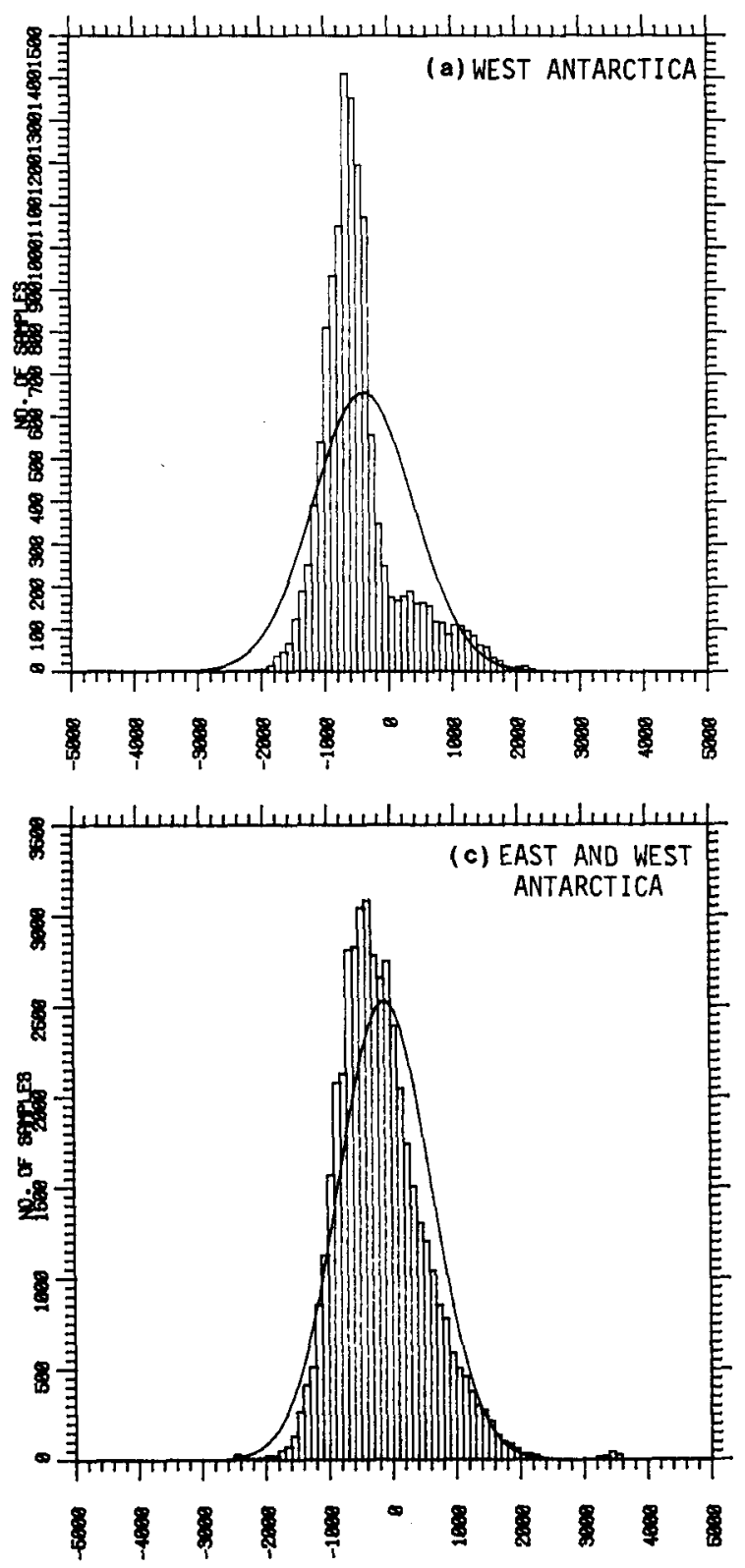

ELEYTION
It is interesting to note results for the two major ice shelves. Traditionally the Ross Ice Shelf has always been considered the larger. In terms of floating ice extent this is still true (compare $0.526 \times 10^{6} \mathrm{~km}^{2}$ for the Ross Ice Shelf with

$0.473 \times 10^{6} \mathrm{~km}^{2}$ for the Ronne-Filchner ice shelves). The total area of the' two ice shelves including all ice rises is now almost identical. This change comes as a result of refinement of the grounding line of the Ronne-Filchner ice shelves from satellite mapping and RES (Swithinbank and others 1976, Drewry and others 1980). The Ronne-Filchner ice sheives possess considerably thicker ice than found in the Ross Ice Shelf, due principally to the flow constraint imposed by large ice rises distributed across the ice shelf: they inhibit large-scale creep-thinning and thicken ice up-stream. The thicker ice results in a total ice volume for the Ronne-Filchner ice shelves considerably in excess of the Ross Ice Shelf.

BEDROCK EL. FOR ICE CPP

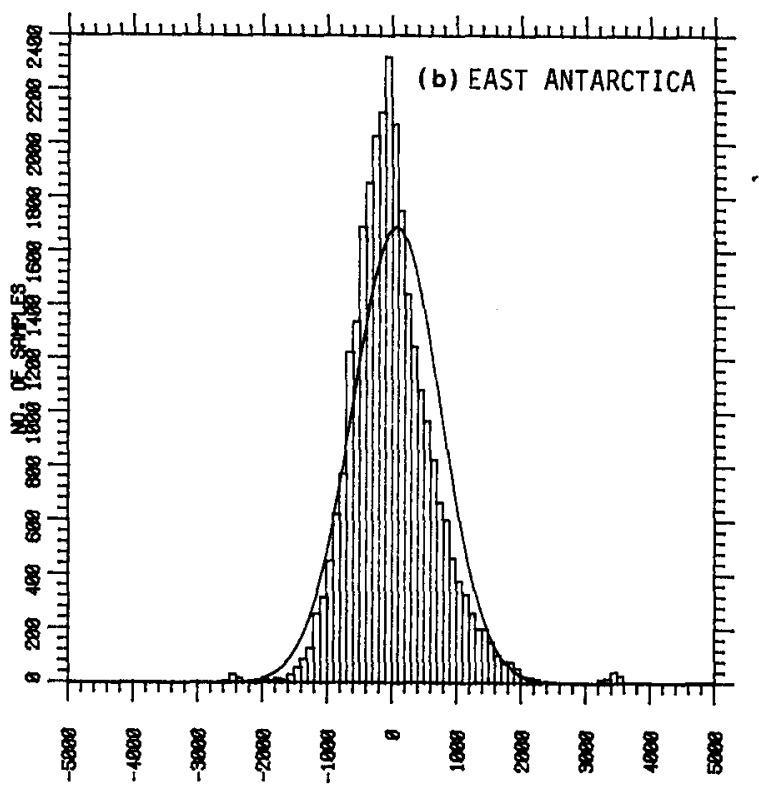

ELEVATION

Fig.4. Histograms of the frequency distribution of bedrock elevations in (a) West and (b) East Antarctica (and (c) combined data). The curve for the normal frequency is given by:

$$
g(x)=\frac{(\text { in })}{\sigma / 2 \pi} \exp \left(\frac{-(x-\bar{x})^{2}}{2(\sigma)^{2}}\right),
$$

where $i$ is class interval, $n$ is number of sample, $\sigma$ is sample RMS deviation, and $x$ is measured variable with mean $\bar{x}$. 
6. SUBGLACIAL BEDROCK CHARACTERISTICS

RES and all other available data on subglacial topography have been combined and contoured. In areas of high data coverage (i.e. parts of East and West Antarctica within the RES grid) the contour interval is $250 \mathrm{~m}$. Elsewhere the contour interval is $500 \mathrm{~m}$. Maps of selected regions have already been published (Jankowski and Drewry 1981, Steed and Drewry in press). The continental map depicting subglacial configuration will be published in the Antarctic folio at a scale of 1:6000 000. In this paper we briefly discuss some of the broad characteristics of the data

Figure 4 depicts histograms for RES-derived bedrock elevations in East, West, and for all Antarctica covered by RES grid $(\sim 50 \%)$. Gaussian functions (taking the same area and with sample RMS deviation) have been fitted to the frequency distributions. It can be seen that East Antarctic data conform closely to a normal distribution ( a $x^{2}$ test indicates that the observed and normal distributions are similar at the $99 \%$ level). The data for combined East and West Antarctica show similar statistical features. The West Antarctic histogram is more positively skewed and less "normal". This is probably accounted for by failure of the RES system to detect deep bedrock in the vicinity of the Bentley Trough and parts of the Byrd subglacial basin. I ce thicknesses here are in excess of $4 \mathrm{~km}$ and two-way dielectric absorption high (up to $110 \mathrm{~dB}$ ) as a result of warmer ice temperatures (mean annual surface temperature $>-30^{\circ} \mathrm{C}$ ). Nevertheless a $x^{2}$ test indicates similarity with normal frequency curve at $95 \%$ level.

The Gaussian characteristics of the bedrock elevations enable several other studies to be undertaken which rely on this statistical assumption, such as the adjustment of elevations for the isostatic effects of superimposed ice load (Jankowski unpublished, Steed unpublished). Table IV summarizes the principal elements of the bedrock surface in Antarctica from SPRI RES data.

TABLE IV. SUBGLACIAL BEDROCK CHARACTERISTICS

\begin{tabular}{|c|c|c|c|}
\hline $\begin{array}{l}\text { Mean bed } \\
\text { elevation } \\
\text { (m) }\end{array}$ & East & West & Continent \\
\hline
\end{tabular}

1. Thiel

2. Bardin and Suyetova

3. Averyanov

4. This paper $+15$ $-440$

(RMS deviation)

(Number of

data points)

$28 \quad 534$

12814

$45 \quad 504$

\section{ACKNOWLEDGEMENTS}

The SPRI RES project was funded under UK Natural Environinent Research Council (NERC) grant GR3/2291. Antarctic airborne field work was conducted under a collaborative programme with the US National Science Foundation and, since 1974-75, with the Technical University of Denmark. The generous logistics support by NSF and US Navy Task Force 199 and Antarctic Development Squadron (VXE-6) is gratefully acknowledged. Preparation of data for the Antarctic glaciological and geophysical folio is funded by NERC, British Petroleum, and Phillips Petroleum. We wish to thank Dr $\mathrm{N}$ Levanon who kindly made available TWERLE data. A P R Cooper assisted with computer processing of data and D Dickens and G Howard with aspects of data reduction.

\section{REFERENCES}

Aver'yanov V G 1980 Morfometricheskiye kharakteristiki lednikovogo pokrova Antarktidy. Informatsionnyy Byulzeten' Sovetskoy Antarkticheskoy Ekspeditsii 100: 5-9

Bardin V I, Suyetova Y A 1967 Basic morphometric characteristics for Antarctica and budget of the Antarctic ice cover. Scientific Reports of the Japanese Antarctic Research Expedition. Special Issue 1: $92-100$

Bentley C R 1964 The structure of Antarctica and its ice cover. In Odishaw $H(e d)$ Research in geophysics 2. Solid earth and interface phenomena. Cambridge, MA, MIT Press: 335-389

British Antarctic Survev 1979 Northern Graham Land and South Shetland Islands. British Antaretic Terpitory geological map, scale 1 : 500,000. Cambridge, British Antarctic Survey (Series BAS $500 \mathrm{G}$ Sheet 2 Edition 1)

Christensen E L 1970 Radioglaciology $300 \mathrm{MHz}$ radar. Lyngby, Technical University of Denmark. Electromagnetics Institute ( $R$ 93)

Crabtree R D 1981 Subglacial morphology in northern Palmer Land, Antarctic Peninsula. Annals of Glaciology 2: 17-22

Crary A P, Robinson E S, Bennett $H F$, Boyd W $W$ Jr 1962 Glaciological studies of the Ross Ice Shelf, Antarctica, 1957-60. IGY Glaciological Reports 6

Directorate of Overseas Surveys 1981 British Antaretic Territory (north of $82^{\circ} \mathrm{S}$ ) with South Georgia and South Shetzand Is zands, scale $1: 3,000,000$. London, Directorate of 0verseas Surveys for the British Antarctic Survey (BAS (Misc) 2 Edition 1)

Orewry D J 1975[a] Comparison of electromagnetic and seismic-gravity ice thickness measurements in East Antarctica. Joumal of Glaciology 15(73): 137-150

Drewry D J 1975[b] Radio echo sounding map of Antarctica, $\left(290^{\circ} \mathrm{E}-180^{\circ}\right)$. Folar Record 17(109): 359-374

Drewry D J 1979 Late Wisconsin reconstruction for the Ross Sea region, Antarctica. Journal of Glaciology 24(90): 231-244

Drewry D J 1981 Radio echo sounding of ice masses: principles and applications. In Cracknell A P (ed) Remote sensing in meteorology, oceanography and hydrology. Chichester, Ell is Horwood: 270-284

Drewry D J (ed) In press. Antarctic gzaciological and geophysical folio. Cambridge, Scott Polar Research Institute

Drewry D J, Jordan S R 1980 Compilation of an Antarctic glaciological and geophysical folio. Polar Record 20 (126): 288

Drewry D J, Meldrum D T 1978 Antarctic airborne radio echo sounding, 1977-78. Polar Record 19(120): 267-273

Drewry D J, Meldrum D T, Jankowski E 1980 Radio echo and magnetic sounding of the Antarctic ice sheet, 1978-79. Polar Record 20(124): 43-51

Evans S, Smith B M E 1969 A radio echo equipment for depth sounding in polar ice sheets. Journal of Scientific Instruments (doumal of Physics E) Ser 2 2: 131-136

Jankowski E J Unpublished. Geophysical studies of the structure of West Antarctica. (PhD thesis, University of Cambridge, 1981)

Jankowski E J, Drewry DJ 1981 The structure of West Antarctica from geophysical studies. Nature 291 (5810): 17-21

Johari G P, Charette P A 1975 The permittivity and attenuation in polycrystalline and singlecrystal ice In at 35 and $60 \mathrm{MHz}$. Journal of Glaciology 14(71): 293-303 
Kayton M 1969 Inertial navigation. In Kayton M, Fried W R (eds) Avionics navigation systems. New York, Wiley: 281-341

Korotkevich Ye S 1968 Ploshchad' ne pokrytoy l'dom territorij Antarktidy [Ice free area of

Antarctica]. Informatsionnyy Byulzeten' Sovetskoy Antarkticheskoy Ekspeditsii 70: 5-6

Levanon N 1982 Antarctic ice elevation maps from balloon altimetry. Annals of Glaciology 3: 184-188

Levanon N, Bentley C R 1979 Ice elevation map of Queen Maud Land, Antarctica, from balloon al timetry. Nature 278(5707): 842-844

Levanon N, Julian P R, Suomi VE 1977 Antarctic topography from balloons. Nature 268(5620): $514-$ 516

MacDonald W R 1976 Antarctic cartography. In Williams R S Jr, Carter W D (eds) ERTS-1. A new window on our planet. United States Geological Survey. Professional Paper 929: 37-43

Ministerstvo Morskogo Flota SSSR 1975 Karta Antarktidy. Masshtab 1:3,000,000 po parazlezi $71^{\circ}$. [Moscow], Ministerstvo Morskogo Flota SSSR (9 listov)

Rob in $G$ de $Q 1975$ Velocity of radio waves in ice by means of a bore-hole interferometric technique. Journal of Glaciology 15(73): 151-159

Robin $G$ de $Q 1981$ Polar ice sheets: developments since Wegener. Geologische Rundschau 70(1-2): 648-663

Robin G de Q, Evans S, Bailey J T 1969 Interpretation of radio echo sounding in polar ice sheets. Philosophical Transactions of the Royal Scsiety of London Ser A 265(1166): 437-505

Rose KE R Unpublished. Radio echo sounding studies of Marie Byrd Land, Antarctica. (PhD thesis, University of Cambridge, 1978)

Shabtaie S, Bentley C R 1982 Measurement of radio wave velocities in the firn zones of polar ice sheets. Annals of Glaciology 3: 342

Shabtaie S, Bentley C R, Blankenship D D, Lovell J S, Gassett R M 1980 Dome C geophysical survey 197980. Antarctic Journal of the United States 15(5): 2-5

Skou N, Søndergaard F 1976 Radioglaciology. A $60 \mathrm{MHz}$ ice sounder system. Lyngby, Technical University of Denmark. Electromagnetics Institute (R 169)

Smith B ME 1972 Airborne radio echo sounding of glaciers in the Antarctic Peninsula. British Antarctic Sumey. Scientific Reports 72

Steed R H N Unpublished. Geophysical studies of Wilkes Land, Antarctica. (PhD thesis, University of Cambridge, 1980)

Steed R H N, Drewry D J In press. Radio echo sounding investigations of Wilkes Land, Antarctica. In Craddock C (ed) Antaretic geoscience. Madison, Wisconsin, University of Wisconsin Press

Swithinbank C W M 1968 Radio echo sounding of Antarctic glaciers from light aircraft. International Association of Scientific Hydrology Publication 79 (General Assembly of Berm. $1967-$ Snow and Ice): 405-414

Swithinbank C W M 1974 A new map of Alexander Island, Antarctica. Polar Record 17(107): 155157

Swithinbank C W M 1977 Glaciological research in the Antarctic Peninsula. Philosophical Transactions of the Royal Society of London Ser B 279(963): 161-183

Swithinbank C W M, Doake C, Wager A, Crabtree $R$

1976 Major change in the map of Antarctica. Polar Record 18(114): 295-299

Thiel E C 1962 The amount of ice on planet Earth. In wex ler $\mathrm{H}$, Rub in M J, Caskey J E (eds) Antaretic research. Washington, DC, American Geophysical Union: 172-175 (Geophysical Monographs 7)
Thomas R H, MacAyeal D R, Bentley C R, Clapp J L 1980 The creep of ice, geothermal heat flow, and Roosevelt Island, Antarctica. Journal of Glaciology 25(91): 47-60

Vinnik A B, Dubovskoy B V, Koblents Ya $P$, Korotkevich Ye S 1976 Novyye dannyye po osnovnym morfometricheskim kharakteristikam Antarktidy. Informatsionnyy Byulzeten' Sovetskoy Antarkticheskoy Ekspeditsii 93: 13-18

Zwally $\mathrm{H} \mathrm{J}$, Bindschadler $\mathrm{R}$, Thomas $\mathrm{R} H$, Martin $T$ 1982 Ice sheet surface topography from Seasat radar altimetry. Annals of Glaciology 3: 350 